\title{
IDENTIFIKASI EKTOPARASIT PADA KEPITING BAKAU (SCYLLA SERRATA) DARI HASIL TANGKAPAN NELAYAN DI WILAYAH PERTAMBAKAN DESA SEGINTUNG, KUALA PEMBUANG II
}

\author{
Leni Handayani ${ }^{1)}$ dan Iftisar Rozikin ${ }^{2)}$ \\ Program Studi Budidaya Perairan Fakultas Pertanian Universitas Darwan Ali Kampus Kuala Pembuang \\ Jl. Kihajar Dewantara, Kuala Pembuang Kabupaten Seruyan, Pos 74212 \\ E-mail : leni.handayani@unda.ac.id ${ }^{1)}$,tisarift@gmail.com ${ }^{2}$
}

\begin{abstract}
ABSTRAK
Penelitian ini bertujuan untuk mengetahui jenis ektoparasit yang menyerang ketiting bakau (Scylla serrata) dan untuk mengetahui tingkat intensitas, prevalensi dan dominasi ektoparasit yang teridentifikasi. Metode yang digunakan dalam penelitian ini adalah metode survei dengan teknik pengambilan sampel yang digunakan untuk menginventarisasi parasit yang ditemukan pada kepiting bakau (Scylla serrata). Metode pengambilan data dilakukan dengan metode observasi lapangan yang dilakukan pada daerah pertambakan masyarakat Desa Segintung. Sampel yang diambil berupa kepiting bakau yang masih hidup sebanyak 100 ekor. Pengamatan ektoparasit dilakukan dengan metode smear dibagian eksternal kepiting bakau (Scylla serrata) yaitu bagian karapaks, kaki jalan, kaki renang dan insang. Penelitiaan ini dilaksanakan pada bulan oktober - november 2018. Parameter yang diamati dalam penelitian ini meliputi prevalensi, intensitas dan dominasi ektoparasit pada kepiting bakau (Scylla serrata) dan data hasil penelitian dianalisa secara deskriftif Hasil penelitian menunjukan bahwa terdapat 4 jenis ektoparasit pada kepiting bakau (Scylla serrata) yaitu Octolasmis sp, Vorticella, Zoothamnium, dan Epistylis sp. Parasit Octolasmis sp. hanya menyerang bagian insang saja. Zoothamnium sp menyerang bagian karapaks dan insang. Vorticella sp dan Epistylis sp menyerang semua bagian mikrobahitat yang diamati pada penelitian ini (kaki jalan, kaki renang, karapaks dan insang). Jumlah parasit terbanyak ditemukan pada bagian karapaks yaitu 658 individu. intensitas serangan parasit tertinggi yang menyerang kepiting bakau adalah parasit Zoothamnium sp dengan intensitas serangan sedang. Prevalensi tertinggi terdapat pada parasit Octolasmis sp dengan nilai prevalensi sebesar $0.62 \%$. Parasit yang menyerang kepiting bakau didominasi oleh parasit Epistylis sp yaitu dengan nilai dominasi sebesar $46.05 \%$
\end{abstract}

Kata Kunci : kepiting bakau, ektoparasit, identifikas, intensitas

\section{PENDAHULUAN}

Desa Segintung merupakan salah satu wilayah yang ada di Kabupaten Seruyan yang banyak terdapat tambak para petani ikan. Daerah ini terletak didaerah yang tidak jauh dari pantai sehingga memungkinkan masyarakat untuk melakukan kegiatan perikanan. Daerah Segintung juga merupakan daerah mangrove yang merupakan bhabitat kepiting bakau (Scylla serrata). Komoditas yang banyak dipelihara oleh petani ikan adalah ikan bandeng (Chanos chanos), udang. Selain memelihara ikan, sebagian petani ikan banyak yang menangkap kepiting dan kerang, karena kepiting bakau (Scylla serrata) merupakan salah satu komoditas perikanan yang mempunyai nilai ekonomis yang cukup tinggi di Kabupaten Seruyan. Harga kepiting bakau berkisar antara $50.000-150.000$ rupiah.

Hutan mangrove mempunyai fungsi utama untuk kelestarian sumberdaya. Fungsi hutan mangrove secara biologis adalah untuk menghasilkan bahan pelapukan yang menjadi sumber makanan penting bagi plankton, sehingga penting pula bagi keberlanjutan rantai makanan, sebagai tempat memijah dan berkembang biaknya ikan-ikan, kerang, kepiting dan udang, sebagai tempat berlindung Secara ekologis hutan mangrove berfungsi sebagai daerah pemijahan dan daerah pembesaran berbagai jenis ikan, udang, kerang-kerangan dan spesies lainnya. Selain itu serasah mangrove yang jatuh di perairan menjadi sumber pakan biota perairan dan unsur hara yang sangat menentukan produktivitas perikanan di perairan pesisir dan laut. Hutan mangrove dengan sistem perakaran dan canopy yang rapat serta kokoh berfungsi sebagai pelindung daratan dari gempuran gelombang, tsunami, angin topan dan perembesan air laut (Bengen, 2000 dalam Sinaga. R, 2016).

Penelitian tentang ektoparasit pada kepiting bakau (Scylla serrata) mulai banyak dilakukan diantaranya yang dilakukan fitriyanti, dkk (2014) yang memperoleh data bahwa ektoparasit yang menyerang kepiting bakau (Scylla serrata) adalah Octolasmisangulata, Octolasmis, larva cypryid Octolasmis, Vorticella, dan lan-lain. Penelitian juga dilakukan oleh Yulanda, dkk (2017) tentang intensitas dan prevalensi ektoparasit pada kepiting bakau di desa lubuk dammar, kabupaten aceh tamiang. Pada penelitiaan ini ditemukan empat ektoparasit yang menginfeksi kepiting bakau yaitu Epistylis sp, Zoothamnium sp, Octolasmis sp, dan vortivella $\mathrm{sp}$.

Selama ini pasokan kepiting bakau (Scylla serrata) di Kabupaten Seruyan hanya mengandalkan dari hasil 
tangkapan dialam, salah satunya pada daerah pertambakan masyarakat yang diduga kepiting hasil tangkapan tersebut ada yang terserang parasit ikan. Serangan parasit ini ini dapat menyebabkan kerugian dalam segi ekonomi juga dapat menyebabkan menurunnya bobot, ketahanan terhadap pathogen dan bahkan dapat menyebabkan kematian (Pusat Karantina Ikan, 2010).

Berdasarkan dugaan inilah maka peneliti tertarik untuk melaksanakan kegiatan penelitian ini. Tujuan penelitian ini adalah untuk mengetahui jenis ektoparasit yang menyerang ketiting bakau (Scyla serrata) dan untuk mengetahui tingkat intensitas, prevalensi dan dominasi ektoparasit yang teridentifikasi.

\section{RUANG LINGKUP}

Dalam penelitiaan ini permasalahan mencakup:

1. Kepiting bakau (Scylla serrata) merupakan saah satu komoditas penting karena harga jualnya yang cukup tinggi yaitu $50.000-150.000$,- rupiah perkilo gram.

2. Batasan - batasan penelitiaan ini adalah pengambilan sampel dilakukan hanya pada daerah pertambakan desa Segintung .

3. Rencana hasil yang didapat pada penelitiaan ini adalah diharapkan memberikan informasi tenyang ektoparasit yang menyerang kepiting bakau.

\section{BAHAN DAN METODE}

Kepiting bakau yang dijadikan sampel sebanyak 100 ekor, aquadest, larutan $\mathrm{NaCl}$ fisiologis. Penelitiaan ini dilaksanakan pada bulan oktober - November 2018. Metode yang digunakan dalam penelitiaan ini metode survei dengan teknik pengambilan sampel yang digunakan untuk menginventarisasi parasit yang ditemukan pada kepiting bakau (Scylla serrata). Metode pengambilan data dilakukan dengan metode observasi lapangan yang dilakukan pada daerah pertambakan masyarakat Desa Segintung.

\subsection{Pengambilan Sampel}

Sampel yang diambil berupa kepiting bakau yang masih hidup. Sampel diperoleh dari masyarakat sekitar yang menangkap kepiting. Pengambilan sampel dilakukan sebanyak 10\% dari hasil tangkapan yang diperoleh dalam satu hari. Sampel yang diperoleh kemudian dimasukan kedalam sterofoam kemudian dibawa ke laboratorium dan dilakukan pemeriksaan.

\subsection{Pemeriksaan ektoparasit}

Pengamatan ektoparasit dilakukan dengan metode smear dibagian eksternal kepiting bakau (Scylla serrata) yaitu bagian karapaks, kaki jalan, kaki renang dan insang. Hasil smear diletakan pada objek glass, selanjutnya ditetesi $\mathrm{NaCl}$ fisiologis agar tidak kering, kemudian diamati menggunakan mikroskop dan diidentifikasi dengan menggunakan buku Kabata (1985). Bagian karapaks dibuka, kemudian bagian organ dalam dan insang dipisahkan kedalam cawan petri, kemudian semua preparat diamati dan dan parasit dihitung langsung dibawah mikroskop.

Parameter yang diamati dalam penelitiaan ini meliputi prevalensi, intensitas dan dominasi ektoparasit pada kepiting uji. data hasil penelitian dianalisa secara deskriftif.

1. Intensitas Parasit

Pengukuran intensitas parasit yang ditemukan menggunakan rumus Kabata (1985) dalam Yulanda, dkk (2017) yaitu (1) :

$$
\text { I (ind/ekor) }=\frac{\sum \text { parasit yang ditemukan }}{\sum \text { total inang yang terinfeksi }}
$$

2. Prevalensi Parasit

Data hasil sampling akan dihitung prevalensi parasitnya dengan menggunakan rumus Kabata (1985) dalam Yulanda, dkk (2017) yaitu (2) :

$$
\mathrm{P}(\%)=\frac{\sum \text { inangyang terinfeksi }}{\sum \text { inang yang diperiksa }} \times 100 \%
$$

\section{Dominasi Parasit}

Perhitungan dominasi parasit yang menyerang kepiting bakau (Scylla serrata) dari hasil sampling menggunakan rumus Mergo dan Crites, 1986 dalam Fitriyanti.. S, dkk (2016) sebagai berikut (3) :

$\mathrm{D}(\%)=\frac{\sum \text { spesies parasit yang ada pada inang }}{\sum \text { seluruh parasit yang ada pada inang }} \times 100 \%$

Data hasil perhitungan akan disajikan dalam bentuk tabulasi. Hasil perhitungan intensitas dan prevalensi dari ektoparasit yang menginfeksi kepiting bakau (Schylla serrata) dimasukan dalam kategori dibawah ini : 
Tabel 1. Kategori Prevalensi Parasit

\begin{tabular}{ccll}
\hline No & Prevalensi(100\%) & \multicolumn{1}{c}{ Kategori } & \multicolumn{1}{c}{ Keterangan } \\
\hline 1 & $100-99$ & Selalu & Infeksi sangat parah \\
2 & $98-90$ & Hampir selalu & Infeksi parah \\
3 & $89-70$ & Biasanya & Infeksi sedang \\
4 & $69-50$ & Sangat serin & Infeksi sangat sering \\
5 & $49-30$ & Umumny & Infeksi biasa \\
6 & $29-10$ & Sering & Infeksi sering \\
7 & $9-1$ & Kadang & Infeksi kadang \\
8 & $<1-0.1$ & Jarang & Infeksi jarang \\
9 & $<0.1-0.1$ & Sangat jarang & Infeksi sangat jarang \\
10 & $<0.01$ & Hampi tidak pernah & Infeksi tidak pernah \\
\hline
\end{tabular}

Tabel 2. Kategori Intensitas Parasit

\begin{tabular}{ccl}
\hline No & Intensitas (ind/ekor) & \multicolumn{1}{c}{ Kategori } \\
\hline 1 & $<1$ & Sangat rendah \\
2 & $1-5$ & Rendah \\
3 & $6-55$ & Sedang \\
4 & $51-100$ & Parah \\
5 & $>100$ & Sangat parah \\
6 & $>1000$ & Super Infeksi \\
\hline
\end{tabular}

\section{PEMBAHASAN}

Berdasarkan hasil yang diperoleh pada kegiatan penelitiaan pada kepiting bakau (Scylla serrata) yang diperoleh dari hasil tangkapan masyarakat disekitar pertambakan Desa Segintung ditemukan 4 spesies ektoparasit dari kelompok protozoa dan Arthopoda. Kelompok Arthopoda yaitu Octolasmis sp dan kelompok prozoa yaitu Vorticella, Zoothamnium, dan Epistylis sp. Hasil ini sesuai dengan hasil penelitian Irvansyah, dkk (2012) yang menyebutkan bahwa jenis ektoparasit yang sering menyerang kepiting bakau adalah Vorticella, Zoothamnium, Epistylis sp dan Octolasmis sp.

\subsection{Kelompok Protozoa}

Ektoparasit yang terrmasuk dalam kelompok protozoa adalah :

\section{Vorticella}

Vorticella bersifat soliter, tangkai pada Vorticella sp. dapat memendek dan

Menggulung, pergerakan tersebut maka memungkinkan Vorticella sp. untuk berpindah

Tempat (Muttaqin, I, dkk 2018). Pendapat ini diperkuat oleh pernyataan Aziz, dkk. (2013) bahwa tangkai pada Vorticella sp. dapat memendek dan menggulung ketika distimulasi dengan pergerakan. Menurut Fitriyanti (2016) bahwa Vorticella sp. ditemukan pada kepiting bakau dengan parameter kualitas air kisaran suhu 30-32 ${ }^{\circ} \mathrm{C}$, DO 2,8-5,4 mg/L, pH 7,9-8,7, dan salinitas 19-28\%.

\section{Zoothamnium sp}

Ektoparasit jenis Zoothamnium sp. mempunyai bentuk tubuh seperti lonceng terbalik, berkontraktil, hidup secara berkoloni dengan banyak cabang di setiap tangkainya, dan berwarna transparan. Zoothamnium sp. memiliki bagian tubuh antara lain adalah macronucleus, cilia, zooid, dan stalk (Muttaqin, I., dkk. 2018).

3. Epystilis sp

Ektoparasit jenis Epistylis sp. memiliki ciri-ciri bercabang pada setiap tangkainya namun pada bagian tangkainya tidak mengalami pergerakan (noncontractile). Ektoparasit Epistylis sp. tubuhnya berwarna transparan dan pada umumnya membentuk koloni. Epistylis sp. memiliki bagian tubuh antara lain adalah nukleus,

vakuola, cilia, dan stalk (Muttaqin, I., dkk. 2018).

\subsection{Kelompok Arthopoda}

Berdasarkan hasil pengamatan diperoleh ektoparasit dari kelompok Arthopoda yaitu Octolasmis sp. Octolasmis sp. terlihat berwarna putih pucat, berkontraktil, berbentuk seperti kecambah, dan hidup secara berkoloni dan memiliki bagian tubuh antara lain adalah tergum, scutum, peduncle, dan carina (Muttaqin, I., dkk. 2018). Octolasmis sp memiliki tergum yang berfungsi sebagai mulut untuk memasukan nutrisi makanan yang akan diserap, carina yang berfungsi untuk melapisi organ bagian dalam, scutum yang berfungsi sebagai usus yang dapat menyerap nutrisi makanan, capitulum berfungsi sebagai lambung (Irvansyah, dkk 2012).

Data jumlah parasit, tingkat prevalensi dan intensitas ektoparasit yang menginfeksi kepiting bakau (Scylla serrata) dapat dilihat pada tabel 3 di bawah ini 
Tabel 3. Mikrohabitat dan Jumlah parasit pada Kepiting Bakau (Scylla serrata)

\begin{tabular}{lccccc}
\hline \multirow{2}{*}{ Parasit } & \multicolumn{3}{c}{ Jumlah parasit/Mikrohabitat (individu) } & \multirow{2}{*}{$\begin{array}{c}\text { Jumlah Total } \\
\text { (Ind) }\end{array}$} \\
\cline { 2 - 5 } & Kaki Jalan & Kaki Renang & Karapaks & Insang & 190 \\
\hline Vorticella $\mathrm{sp}$ & 40 & 5 & 125 & 20 & 613 \\
Epistylis $\mathrm{sp}$ & 64 & 2 & 431 & 116 & 102 \\
Zoothamnium sp & - & - & 102 & - & 426 \\
Octolasmis sp & - & - & - & 426 & $\mathbf{1 3 3 1}$ \\
\hline \multicolumn{1}{c}{ Jumlah } & $\mathbf{1 0 4}$ & $\mathbf{7}$ & $\mathbf{6 5 8}$ & $\mathbf{5 6 2}$ & \\
\hline
\end{tabular}

Berdasarkan hasil pengamatan. Parasit Octolasmis sp. hanya menyerang bagian insang saja, hal ini sejalan dengan pendapat Menurut Irvansyah , dkk (2012) bahwa Octolasmis sp. hanya ditemukan pada bagian organ insang dikarenakan siklus hidup dari Octolasmis sp. membutuhkan kebutuhan nutrisi yang lebih untuk hidup dan berkembangnya. Insang merupakan organ yang paling sering dialiri darah,terdapat pembuluh-pembuluh darah dan pelindungnya berupa jaringan epitel selapis yang tipis sehingga ektoparasit tersebut sangat mudah diserang. sedangkan Zoothamnium sp menyerang bagian karapaks dan insang. Vorticella $\mathrm{sp}$ dan Epistylis sp menyerang semua bagian mikrobahitat yang diamati pada penelitian ini (kaki jalan, kaki renang, karapaks dan insang). Jumlah parasit terbanyak ditemukan pada bagian karapaks yaitu 658 individu.

Tabel 4. Nilai Intensitas, Prevalensi dan Dominasi Ektoparasit pada Kepiting Bakau (Scylla serrata)

\begin{tabular}{clcccccc}
\hline No & \multicolumn{1}{c}{ Parasit } & $\begin{array}{c}\text { Jumlah } \\
\text { Parasit }\end{array}$ & $\begin{array}{c}\text { Jumlah } \\
\text { Sampel }\end{array}$ & $\begin{array}{c}\text { Jumlah } \\
\text { Sampel } \\
\text { Terinfeksi }\end{array}$ & $\begin{array}{c}\text { Intensitas } \\
\text { (Ind/ekor) }\end{array}$ & $\begin{array}{c}\text { Prevalensi } \\
(\%)\end{array}$ & $\begin{array}{c}\text { Dominasi } \\
(\%)\end{array}$ \\
\hline 1 & Vorticella sp & 426 & 100 & 26 & 16 & 0.26 & 32.00 \\
2 & Epistylis $\mathrm{sp}$ & 613 & 100 & 20 & 31 & 0.20 & 46.05 \\
3 & Zoothamnium sp & 102 & 100 & 3 & 34 & 0.03 & 7.66 \\
4 & Octolasmis $\mathrm{sp}$ & 462 & 100 & 62 & 7 & 0.62 & 34.71 \\
\hline
\end{tabular}

Berdasarkan Tabel 4 intensitas serangan parasit tertinggi yang menyerang kepiting bakau adalah parasit Zoothamnium sp dengan nilai intensitas 34 ind/ekor yang dikategorikan intensitas serangan sedang dan yang terendah adalah parasit Octolasmis sp (7 ind/ekor) dengan intensitas serangan sedang. Menurut Mahasri (2008), Zoothamnium sp merupakan organisme parasit yang bisa hidup normal pada perairan berkualitas sehingga meskipun kualitas perairan baik, parasit ini akan tetap bisa tumbuh, namun kelimpahan Zoothamnium sp pada kepiting bakau yang diamati masih tergolong wajar selama tidak mengakibatkan mortalitas yang tinggi.

Prevalensi tertinggi terdapat pada parasit Octolasmis sp dengan nilai prevalensi sebesar $0.62 \%$ dan yang terendah adalah parasit Zoothamnium sp yaitu sebesar $0.03 \%$. prevalensi yang terjadi pada kepiting bakau yang diamati diketegorikan infeksi yang terjadi masih jarang untuk menyerang kepiting bakau. Menurut Diba dalam Wiyatno, dkk (2012) rendahnya tingkat prevalensi disebabkan oleh keadaan endemik suatu parasit dan kualitas lingkungan.

Prevalensi dan Intensitas tiap jenis parasit tidak selalu sama karena banyaknyafaktor yang berpengaruh, salah satu faktor yang berpengaruh adalah ukuran inang. Pada beberapa spesies semakin besar ukuran/berat inang, semakin tinggi infeksi oleh parasit tertentu. Inang yang lebih tua dapat mengandung jumlah parasit yang lebih besar, meskipun apabila telah terjadi saling adaptas imaka inang menjadi toleran terhadap parasitnya (Noble and Noble (1989) dalam Aria (2008) dalam Suhardi, dkk (2014).

Parasit yang menyerang kepiting bakau didominasi oleh parasit Epistylis sp yaitu dengan nilai dominasi sebesar $46.05 \%$. Menurut Polyanski dalam Romagia, S (2001) dalam Umasugi dan Burhanuddin (2015) menyatakan bahwa tingkat kehadiran parasit berdasarkan umur, dapat dibagi menjadi tiga kondisi yaitu jumlah parasit bertambah dengan bertambahnya umur inang, kehadiran parasit berkurang dengan bertambahnya umur inang, dan kehadiran parasit tidak dipengaruhi oleh umur inang.

\section{KESIMPULAN}

Berdasarkan hasil pengamatan yang telah dilakukan maka diperoleh kesimpulan bahwa ada 4 jenis ektoparasit pada kepiting bakau (Scylla serrata) yaitu Octolasmis sp, yaitu Vorticella, Zoothamnium, dan Epistylis sp. Intensitas serangan parasit tertinggi yang menyerang kepiting bakau adalah parasit Zoothamnium sp dengan nilai intensitas 34 ind/ekor yang dikategorikan intensitas serangan sedang dan yang terendah adalah parasit Octolasmis sp yaitu 7 ind/ekor dengan intensitas serangan sedang. Prevalensi tertinggi terdapat pada parasit Octolasmis sp dengan nilai prevalensi sebesar $0.62 \%$ dan yang terendah adalah parasit Zoothamnium $\mathrm{sp}$ yaitu sebesar $0.03 \%$. Parasit yang menyerang kepiting 
bakau didominasi oleh parasit Epistylis sp yaitu dengan nilai dominasi sebesar $46.05 \%$.

\section{SARAN}

Adanya penelitian lanjutan tentang pengamatan terhadap kepiting bakau karena kepiting bakau merupakan salah satu komoditas yang mempunyai nilai ekonomis yang tinggi dengan harga jual yang cukup tinggi.

\section{DAFTAR PUSTAKA}

Azis, I., Heppi dan Darto. 2013. Identifikasi Ektoparasit pada Udang Windu (Panaeus monodon) di Tambak Tradisional Kota Tarakan. Tesis. Universitas Borneo Tarakan. Tarakan.

Fitriyanti, S. 2016. Keanekaragaman Ektoparasit Kepiting Bakau (Schylla serrata) dari Perairan Tambak Desa Wonosari Kabupaten Kendal. Semarang. Fakultas Perikanan dan Ilmu Kelautan. Universitas Diponegoro. Semarang

Fitriyanti. S, Desrina, dan Haditomo. C.A.H. 2014. Ektoparasit Kepiting Bakau (Scylla serrata) Dari Perairan Desa Wonosari,Kabupaten Kendal. Prosiding Seminar Nasional Hasil-Hasil Penelitian Perikanan dan Kelautan ke VI. Fakultas Perikanan dan Kelautan-Pusat Kajian Mitigasi Bencana dan Rehabilitasi Pesisir. UNDIP.

Irvansyah, M.Y.A. Nurlita dan M. Gunanti. 2012Identifikasi dan Itensitas Ektoparasit Pada Kepiting Bakau (Scylla serrata) Stadia Kepiting Muda di Pertambakan Kepiting Kecamatan Sedati, Kabupaten Sidoarjo. Jurnal Sains dan Seni ITS, 1 (1). Departemen Perikanan.Fakultas Perikanan. Universitas Airlangga. Surabaya.

Mahasri, G., L. Raya, A.S. Mubarak dan B. Irawan. 2008. Gambaran Patologi Insang dan Kulit Udang Windu (Panaeus monodon Fab) yang Terserang Ciliata Patogen dari Famili Vorticellidae (Zoothamniumsp) Berkala Ilmiah Perikanan, 3 (1)

Muttaqin. I, dkk. 2018. Identifikasi dan Predileksi Ektoparasit Kepiting Bakau (Scylla serrata) dari Ekosistem Mangrove Taman Hutan Raya (TAHURA) Ngurahrai. Bali.

Pusat Karantina Ikan- KKP. 2010. Mengenal Octolasmis, Parasit Leher Angsa pada Crustacea. Info Karantina Ikan Edisi 7 Vol. 1.

Sinaga. R. 2016. Strategi Pengelolaan Hutan Mangrove Terhadap Hasil Tangkapan Kepiting Bakau (Scylla sp) Dengan Alat Tangkap Bubu di Desa Alang-Alang Kuala.Universitas Jambi. Jambi

Suhardi, Raharjo,E. I, danSunarto. 2014. Tingkat Serangan Ektoparasit Pada Ikan Patin (Pangasius hypophtalmus) Yang Dibudidayakan Dalam Karamba Di Sungai Kapuas Kota Pontianak. Jurnal Ruaya Vol.1 No.1.
Umasugi, S dan Burhanuddin, S. 2015.Analisis Prevalensi dan Intensitas Ektoparasit Ikan Kerapu Tikus (Cromileptes altevalis) Di Keramba Jaring apung Perairan Teluk Kayeli Kabupaten Buru. Jurnal Ilmuah Agribisnis dan Perikanan Vol 8 Edisi 1. Ternate

Wiyatno, F.H., Subekti, S dan Kusdarwati. R.2012. Identifikasi dan Prevalensi Ektoparasit pada Kerapu Tikus (Cromileptes altivelis) Di Karamba Jaring Apung Unit Pengelola Budidaya Laut Situbondo. Jurnal Ilmiah Perikanan dan Kelautan Vol. 4 No. 1.

Yulanda. E.I, Dewiyanti. I dan Aliza. D. 2017.Intensitas dan Prevalensi Ektoparasit Pada Kepiting Bakau (Scylla serrata) Di Desa Lubuk Damar, Kabupaten Aceh Tamiang. Jurnal Ilmuah Mahasiswa Kelautan dan Perikanan Unsyiah. Vol 2 no. 11 